\title{
Spiseforstyrrelser blandt kvindelige eliteidrætsudøvere
}

\section{Af Eva Wulff Helge}

The female atblete triad-eller den kvindelige idratstriade - er karakteriseret ved den samtidige tilstedevarelse af tre symptomer: Spiseforstyrrelser, menstruationsforstyrrelser og lav knogletethed. Med udgangspunkt $i$ den forogede forekomst af spiseforstyrrelser blandt kvindelige eliteidratsudøvere redegor artiklen for de enkelte symptomer på triaden og diskuterer deves indbyrdes sammenhang. Der argumenteres for at en stor forebyggende indsats er nødvendig.

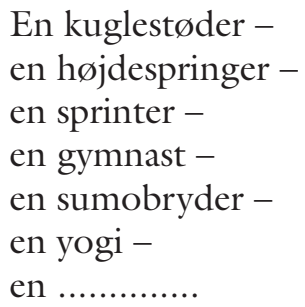

Vi kan se dem for os. Vi ved, hvordan de ser ud. Kropsbilleder, billeder af kroppen, billeder med kroppen. Signaler - om hvem jeg er - om hvad jeg er - om hvad jeg gør. Klæder skaber folk, men tøjet er ikke nok. Krop skaber folk: Her er jeg. Hvem er jeg? Kroppen kan man ikke løbe fra - den kan man løbe med. Eller kæmpe imod - indtil den har indordnet sig. Fordringen er den tynde krop, men med hvilke midler og med hvilken konsekvens?

I dagens samfund er den slanke krop idealet: Et signal om ungdom, sundhed, aktivitet, viljestyrke og kontrol; et mål som træning og den rette kost kan være midler til at opnå. For de fleste eliteidrætsudøvere er den slanke krop tillige et middel til at 
opnå en høj præstationsevne. Kravet om kropslig effektivitet og funktionalisme gør, at vi kan kende idrættens eliteudøvere fra hinanden: Jo større specialisering inden for en idrætsgren, desto større er kravet til kroppens proportioner og vægt, når den ultimative idrætspræstation er i højsædet. De rette gener og den rigtige træning vil medvirke til at forme kroppen. Men træning er ikke altid tilstrækkeligt til at blive slank nok, og for nogle kan en almindelig slankekur udvikle sig til spiseforstyrret adfærd eller kliniske spiseforstyrrelser karakteriseret ved et tvangsmæssigt forhold til krop og kost.

I det følgende vil forekomsten af spiseforstyrrelser blandt eliteidrætskvinder blive behandlet med disse spørgsmål som omdrejningspunkter: Hvad er en spiseforstyrrelse? Udgør spiseforstyrrelser et særligt problem inden for idrætten? Hvordan påvirker spiseforstyrrelser/for lavt energiindtag den hormonale balance og knoglesundheden?

\section{AT HAVE EN SPISEFORSTYRRELSE \\ - ET FORSTYRRET FORHOLD TIL KROP OG KOST}

Har man en spiseforstyrrelse, er det et helt dominerende mål at tabe sig eller at opretholde sin kropsvagt. De kliniske spiseforstyrrelser bulimia nervosa (vekslende xdeflip og 'tømninger') og anorexia nervosa (fornægtelse af lysten og behovet for at spise) er nok de mest alment kendte spiseforstyrrelser, men begrebet er meget videre. Eksempelvis omfatter den kliniske diagnose ED-NOS (atypiske spiseforstyrrelser) i følge den amerikanske diagnoseliste Diagnostic and Statistical Manual of Mental Disorders, DSM-IV, lettere former for behandlingskrævende spiseforstyrrelser, som ikke opfylder samtlige diagnosekriterier for henholdsvis bulimi eller anoreksi (Sundhedsstyrelsen 1997), og de fleste tilfælde af spiseforstyrrelser inden for eliteidret er at finde inden for denne gruppe. (For en nærmere beskrivelse af diagnosekri- terier henvises til DSM-IV (American Psychiatric Association, 1994) og The International Classification of Diseases ICD-10 (WHO 1992)). Ud over disse kliniske spiseforstyrrelser er beskrevet anorexia athletica, som er en spiseforstyrrelse specifik for idrætsudøvere (Sundgot-Borgen 1994), ligesom der eksisterer forskellige grader af spiseforstyrret adfærd (subkliniske spiseforstyrrelser), hvor der ikke er tale om egentlig sygdom i klinisk forstand, men om såkaldt risikoadfærd for udvikling af spiseforstyrrelser (Waaddegaard 2002).

\section{SPISEFORSTYRRET ADFÆRD - RISIKOADFÆRD}

I idrætsgrene hvor kropsvægten objektivt set er af stor betydning for prestationsevnen, eksisterer der i nogle træningsmiljøer en overdreven fokusering på lav kropsvægt og lav fedtprocent som midler til at øge præstationsevnen. Denne kollektive vægtfokusering indebærer en stor risiko for, at slankningen 'løber af sporet': Et dominerende mål bliver at tabe sig eller at opretholde sin lave vægt, hvilket realiseres ved et vedvarende lavt energiindtag. Herved bliver den tilgxngelige energi til vedligeholdelse af kroppens almindelige funktioner utilstrækkelig med negative konsekvenser for individets almene helbred.

I idrætskredse er der uenighed om, hvor alvorligt man bør tage nogle udøveres ekstreme spise- og træningsadfærd. I og med at vægtregulering inden for visse eliteidrætsmiljøer er blevet en naturlig - og til tider nødvendig - del af 'trænings-regimet', kan det i praksis være vanskeligt for trænere og andre at afgrænse symptomer på spiseforstyrrelser fra udøvernes 'almindelige' præstationsfremmende adfærd: Eksempelvis det at veje sig efter alle måltider og alle træninger, konsekvent at løbe 2 timer morgen og aften med det formål at holde vægten nede, fra tid til anden at faste $\mathrm{i}$ et par dage, eller at gå i sauna med tøj på for hurtigt at reducere vægten. Men under alle 


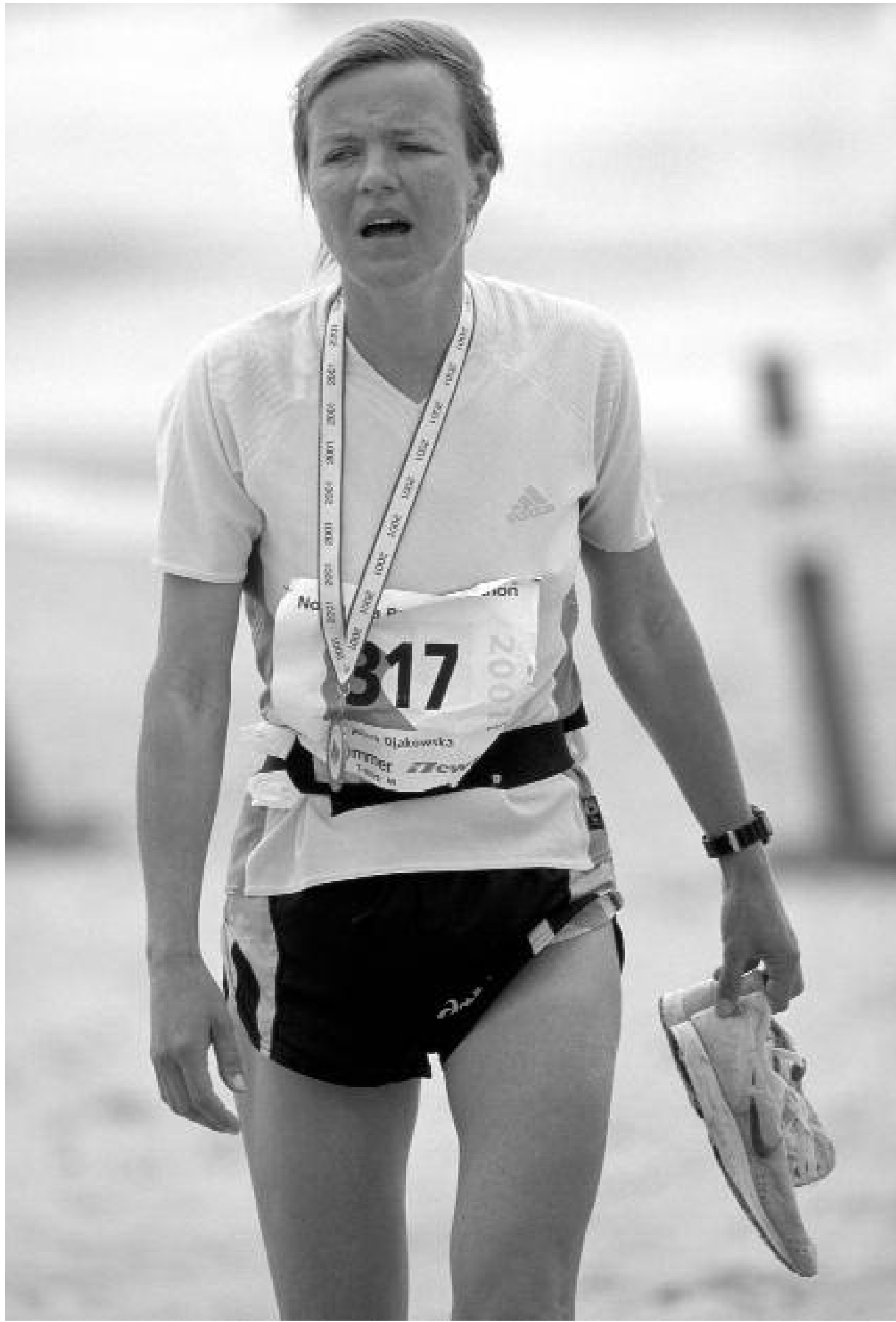


omstændigheder er der her tale om risikoadfærd for udvikling af kliniske spiseforstyrelser.

Endvidere benytter nogle udøvere i det skjulte vanddrivende midler, slankepiller og afføringsmidler, herunder lægeordineret medicin, som vægtregulerende midler, hvilket har en negativ effekt på både sundhed og præstationsevne. Således har man i xstetiske idrætsgrene og kampidrætter fundet, at mere end hver sjette kvindelige eliteudøver brugte en eller flere af disse metoder til regulering af kropsvægten. Af nogle opfattes det som ganske almindeligt i perioder at benytte disse vægtreguleringsmetoder til at holde vægten nede, og i nogle miljøer anses det ligefrem for at være normen $-\mathrm{ja}$, måske endda beviset på, at man er både handlekraftig og målrettet.

Imidlertid kan spiseforstyrret adfærd ikke ses som et isoleret fænomen. Nu og her fører det til generelt dårligt helbred og social isolation, og ved udvikling af kliniske spiseforstyrrelser vil der ofte være en kontinuert overgang fra almindelig optagethed af sundhed via slankekure og tvangsmæssige spisevaner til egentlige sygdomstilstande. I et studie blandt danske unge har Waaddegaard (2002) defineret og undersøgt risikoadfærd for udvikling af spiseforstyrrelser inden for fire områder: Kropsopfattelse, vægtkontrol, spisevaner og selvværdfølelse. Kriteriet for diagnosen risikoadfærd var, at personen inden for hvert af områderne udviste et vist antal symptomer, eksempelvis konstant optagethed af kropsvægt og-form, frygt for at være eller blive tyk, streng kostrestriktion, frygt for kontroltab ved spisning, brug af ekstreme metoder til vægttab, dårlig samvittighed over at spise for meget, ubehag ved at spise sammen med andre, og selvværd afhængigt af kropsvægt og form. Ud fra denne definition på risikoadfærd viste undersøgelsen, at $27.3 \%$ af de unge piger og $2.8 \%$ af de unge drenge udviste risikoadfærd eller havde kliniske spiseforstyrrelser.

Blandt idrætsudøvere er der ikke fore- taget lignende undersøgelser herhjemme, men blandt kvindelige norske elitedrætsudøvere er fundet tilsvarende tal: $21 \%$ havde riskoadfærd for spiseforstyrrelser sammenlignet med 26\% i kontrolgruppen (Sundgot-Borgen 1994). Ved opfølgning på det norske studie fandt man imidlertid, at mens $20 \%$ af kontrollerne med risikoadfærd udviklede en spiseforstyrrelse, gjaldt det $90 \%$ af eliteidrætskvinderne. Dette kunne tolkes derhen, at forhold inden for eliteidrætten kan bidrage til at udløse en klinisk spiseforstyrrelse hos prædisponerede personer med risikoadfærd.

\section{KLINISKE SPISEFORSTYRRELSER}

Spiseforstyrrelser har en foruroligende overhyppighed blandt eliteidrætsudøvere. Den højeste forekomst ses blandt eliteudøvere inden for idrætsgrene, hvor en lav kropsvægt eller udseendet er af stor betydning for præstationsevnen (Sundgot-Borgen 2000, Smolak et al. 2000). Ligesom i det omgivende samfund er forekomsten af spiseforstyrrelser blandt idrætsudøvere størst blandt unge piger og kvinder (Sundgot-Borgen 2000), men også blandt unge drenge og mænd ses en forhøjet forekomst.

Der findes ingen større epidemiologiske studier af problemets omfang blandt idrætsudøvere i Danmark, men blandt norske eliteudøvere har man fundet særdeles høje tal. I et nyligt studie fandt man således, at den gennemsnitlige forekomst af anorexia nervosa, bulimia nervosa, anorexia athletica og ED-NOS blandt kvindelige eliteudøvere var på i alt $20 \%$ (respektive $2 \%, 6 \%, 4 \%$ og $8 \%)$ og blandt mandlige eliteudøvere på i alt $8 \%$ (respektive $0 \%, 2 \%, 1 \%$ og $5 \%$ ) (Sundgot-Borgen \& Torstveit 2004). For kvindernes vedkommende svarede det til en dobbelt så høj forekomst som i kontrolgruppen, og for mændenes vedkommende til en fire gange så høj forekomst som i kontrolgruppen. Blandt kvindelige eliteudøvere var forekomsten højest inden for xstetiske idrætsgrene som gymnastik, ud- 


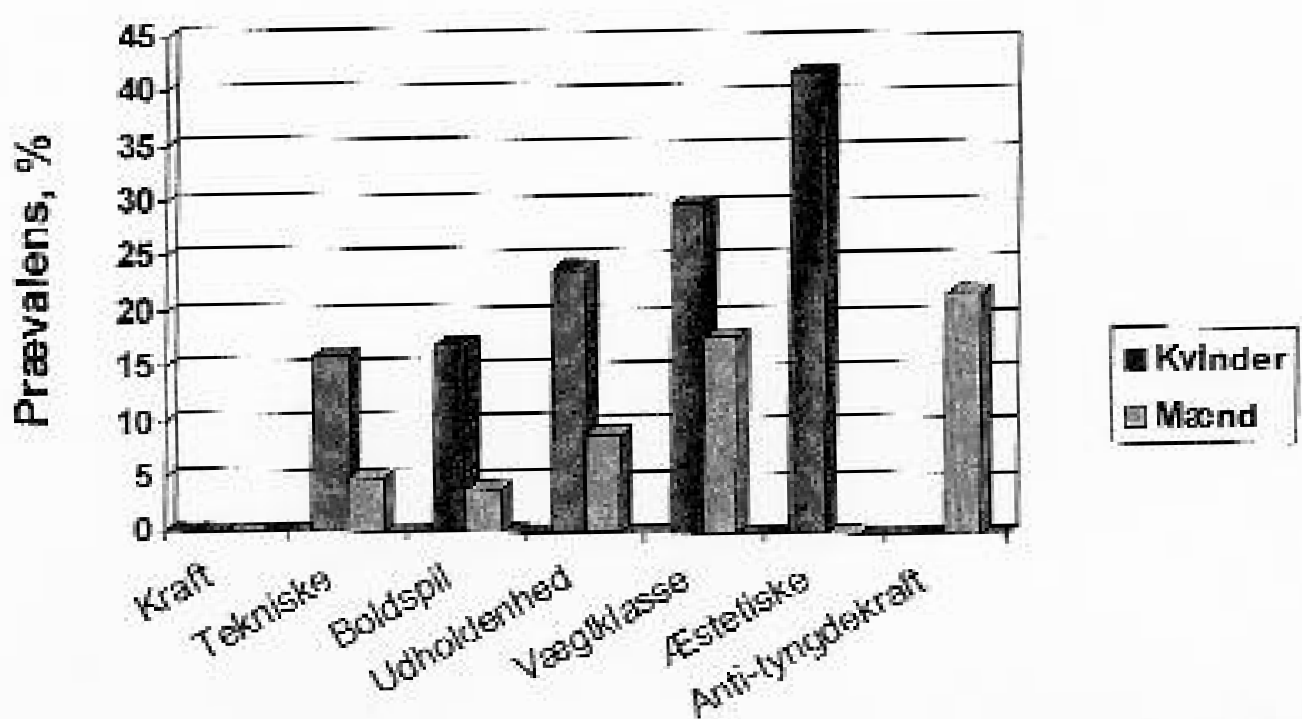

Fig. 1. Forekomsten af spiseforstyrrelser blandt norske kvindelige og mandlige eliteidretsudøvere.

(Efter Sundgot-Borgen \& Torstveit, 2004)

spring og kunstskøjteløb (42\%), inden for vægtklasseidrætter som letvægtsroning og kampidrætter $(30 \%)$ samt inden for udholdenhedsidrætsgrene (24\%). Blandt mandlige eliteudøvere sås ligeledes en forøget forekomst inden for vægtklasseidrætter (18\%) og inden for udholdenhedsidrætsgrene (9\%) (fig. 1).

I en metaanalyse af omfanget af spiseforstyrrelser blandt både motions- og eliteidrætskvinder sås forventeligt et mere varieret billede (Smolak et al. 2000). Analysen baserede sig på 33, hovedsageligt amerikanske, studier fra 1975 til 1999, og det kunne ses, at hverken gymnastik eller løb i sig selv øgede risikoen for spiseforstyrrelser, mens det at dyrke eliteidræt - især idrætsgrene hvor en lav kropsvægt er af betydning for præstationsevnen - indebar en forøget risiko. Imidlertid var der stor variation i forekomsten af spiseforstyrrelser mellem de enkelte studier, hvilket bl.a. afspejlede, at der var brugt forskellige diagnosekriterier, og at den faktiske udvikling af spiseforstyrrelser i høj grad er betinget af de normer og regler, som gxlder i det enkelte idrætsmiljø.

\section{DEN KVINDELIGE IDRÆTSTRIADE}

Hos idrætsudøvere blev den samtidige tilstedeværelse af 1) spiseforstyrrelser, 2) menstruationsforstyrrelser i form af forlænget cyklus (oligomenorré) eller helt udebleven menstruation (amenorré) og 3) knogleskørhed i 1993 defineret som The Female Athlete Triad (Yeager et al. 1993) eller på dansk, Den Kvindelige Idrætstriade. Årsagssammenhængen bag udvikling af den kvindelige idrætstriade er multifaktoriel, men den rådende hypotese er, at en negativ energistatus med lav energitilgængelighed (gennem undertrykkelse af hypothalamusgonadeaksen) fører til lave koncentrationer af kønshormoner (Loucks 2004). Resultatet er oligomenorré/ame-norré og lav knogletæthed (BMD) (fig. 2).

\section{IDRÆTSRELATEREDE}

MENSTRUATIONSFORSTYRRELSER

Forekomsten af amenorré blandt idrætskvinder er i forskellige studier rapporteret at ligge på mellem 3\% og 66\%. Som ved studier af spiseforstyrrelser skyldes variationen bl.a., at der har været tale om 


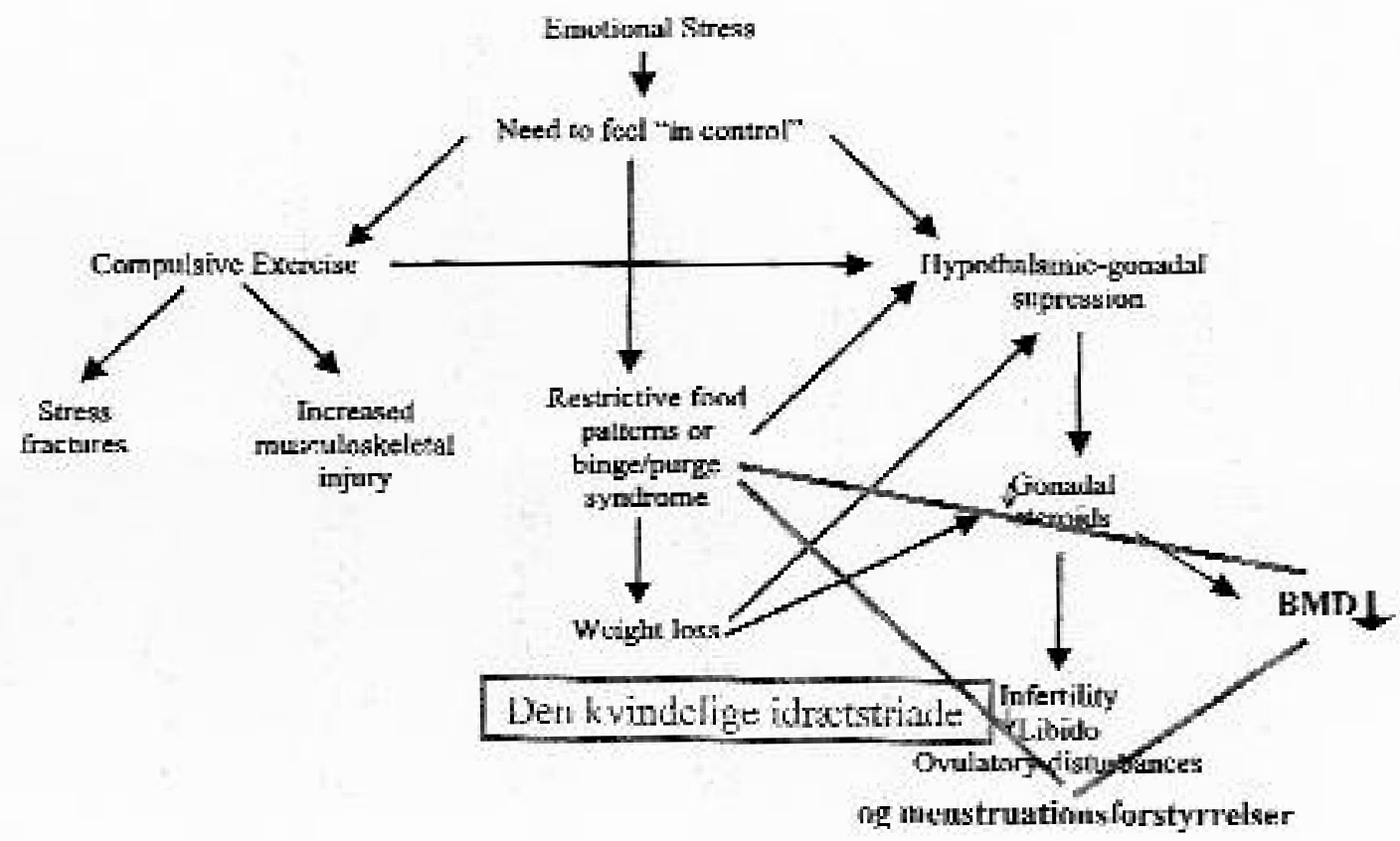

Fig. 2. Relationerne mellem multiple faktorer (stress, tvangspraget traning, restriktiv spisning), der som oftest er relateret til udviklingen af lave koncentrationer af kønshormoner-og dermed til den kvindelige idretstriade (Petit es Prioe 2000).

(Den Kvindelige Idratstriade er tilføjet af artiklens forfatter.)

idrætskvinder på meget forskellige præstationsniveauer og fra forskellige idrætsgrene.

I et studie af danske kvindelige eliteudøvere var forekomsten af amenorré højest i udholdenhedsidrætter og inden for de æstetiske idrætsgrene, hvor op mod hver fjerde af idrætskvinderne aldrig menstruerede (Wulff Hansen 1988). Blandt norske eliteudøvere (Sundgot-Borgen 1999) er forekomsten af menstruationsforstyrrelser ligeledes fundet at være højest i xstetiske idrætsgrene $(30 \%)$ og udholdenhedsidrætter $(20 \%)$. Disse resultater er ligeledes i overensstemmelse med flere amerikanske studier.

Idrætsrelaterede menstruationsforstyrrelser er blevet relateret til faktorerne træningsmængde og -intensitet, kroppens fedtprocent, kost og energistatus samt stress. Umiddelbart tyder det ikke på, at der er en kausal fysiologisk sammenhæng mellem hverken træning eller fedtprocent og menstruationsforstyrrelser. I 1973 fremsatte Frisch den hypotese, at kroppens fedtprocent skulle overstige henholdsvis $17 \%$, for at den forste menstruation (menarken) kunne etableres og $22 \%$ for opretholdelse af fertiliteten. Imidlertid har senere studier vist, at hver enkelt kvinde har sin individuelle tærskel, som primært er genetisk bestemt.

En lav fedtprocent kan imidlertid være udtryk for en negativ energistatus og lav energitilgængelighed, som i dag menes at være den afgørende variabel for undertrykkelse af hypothalamus-gonadeaksen. Til støtte herfor har man hos kvindelige idrætsudøvere med henholdsvis normalt menstruationsmønster (eumenorré) og amenorré fundet, at amenorrégruppen trods en signifikant højere træningsmængde og dermed et større energiforbrug ikke havde et 
større energiindtag. Dette kunne tyde på et energiunderskud hos amenorrégruppen (Harber et al 1998).

\section{RISIKOEN FOR KNOGLESKØRHED}

Det er velkendt, at vægtbærende fysisk aktivitet normalt bevirker en forøgelse af knoglernes mineralindhold - og dermed af knogletxtheden (BMD). Men for 20 år siden registrerede man for første gang en mindsket BMD hos kvindelige løbere, der trænede intensivt (Cann 1984, Drinkwater 1986). BMD i lænderyggen blev rapporteret at være $20-30 \%$ lavere end normalt, svarende til en knoglealder på 70-80 år. Det så altså ud til, at den positive effekt af træningen blev mere end modvirket af en anden faktor. I dag mener man, at den væsentligste faktor er en reduceret koncentration af kønshormoner, som hos løbere hovedsageligt har en negativ effekt på trabekulært knoglevæv i lænderyg og distale radius. En vedvarende lav koncentration af kønshormoner vil alt andet lige føre til et fald i $\mathrm{BMD}$, og er koncentrationen lav i teenageårene og i starten af tyverne, vil resultatet derudover blive en lavere maksimal knoglemasse. Det er fundet, at en reduktion svarende til 1 standardafvigelse $(\mathrm{SD})$ på længere sigt vil øge risikoen for knogleskørhed med 50\% (Marshall 1996).

Det diskuteres, om reduktionen i BMD efter længerevarende præmenopausale menstruationsforstyrrelser er reversibel ved reetablering af den hormonale balance. Hos løbere med amenorré har man efter reetablering af menstruationscyklus fundet en stigning i lænderyggens BMD på 6\% i løbet af de første 15 måneder, men det følgende år var stigningen faldet til 3\%, og herefter lå BMD på et stabilt lavt niveau. Endvidere er omfanget af menstruationsforstyrrelser siden menarken fundet at være omvendt relateret til $\mathrm{BMD}$, hvilket ligeledes indikerer, at der ikke er fuld reversibilitet ved reetablering af den hormonale balance (Gibson 2000). Jo længere tids hormonale forstyr- relser, jo større samtidig reduktion af $\mathrm{BMD}$, og des større risiko for varig reduktion. Tidlig diagnose og behandling er dermed afgørende for det videre forløb.

\section{TRÆNINGENS MEKANISKE PÅVIRKNING AF SKELETTET}

De fleste studier af den kvindelige idrætstriade er blevet udført på løbere, men i de senere år er andre idrætsgrene kommet til. I idrætsgrene med en større mekanisk og mere varieret belastning end $l ø b$, fx redskabs- og springgymnastik, har man fundet, at udøvere trods menstruationsforstyrrelser og lave koncentrationer af kønshormoner er i stand til at opretholde en normal eller forøget BMD. Ligeledes er der hos gymnaster fundet en signifikant sammenhæng mellem regional BMD og maksimal muskelstyrke i den relaterede muskelgruppe (Wulff Helge \& Kanstrup 2002). Det kunne indikere, at den kvindelige idrætstriade er et syndrom, som hovedsageligt findes i idrætsgrene, hvor den mekaniske belastning ved aktiviteten er relativt lav og ikke forudsætter udvikling af stor muskelstyrke, fx mellem- og langdistanceløb.

HM Frost (1992) har opstillet en hypotese for interaktionen mellem biokemiske og mekaniske stimuli i knogleomsætningen (Mechanostatteorien), som giver en mulig forklaring på den varierende betydning af lave koncentrationer af kønshormoner hos idrætskvinder, der udsættes for forskellig mekanisk belastning. Når man bevæger sig, udsættes skelettet for mekanisk belastning fra muskelkræfter og reaktionskræfter fra underlaget. Disse kræfter vil momentant deformere knoglerne, og graden af midlertidig deformation udtrykkes som strain $(\Delta \mathrm{l} / \mathrm{l})$. Ifølge Frosts teori registrerer knoglen det påførte strain i forhold til et såkaldt set-point - eller en tærskelværdi - for knogledannelse. Overstiger knoglens strain ved fysisk aktivitet set-point, vil resultatet være knogleopbygning og dermed på længere sigt adaptation til den mekaniske kraft- 


\section{Mechanostat-teorien \\ (HM Frost: J. Bone Miner.Res. 7: 253-261 1992)}
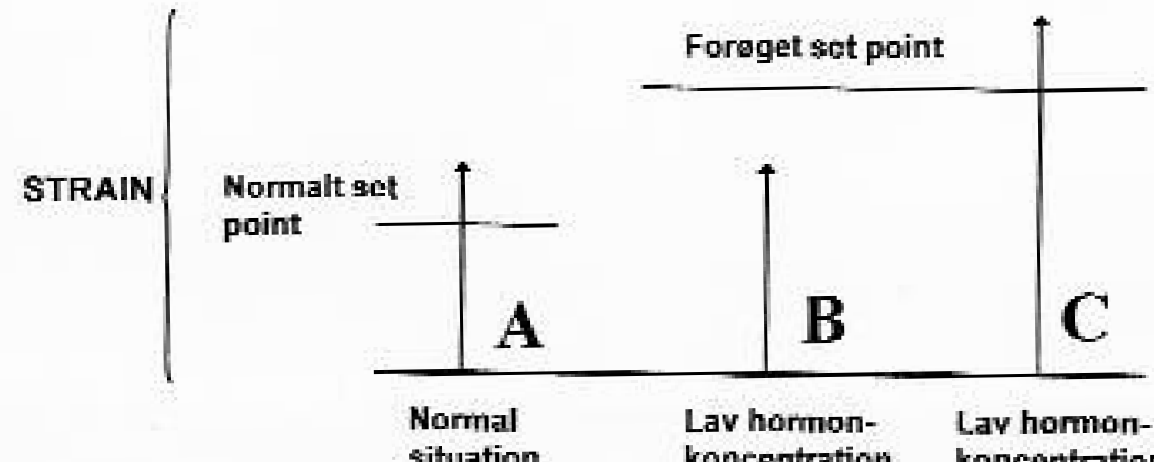

Lav hormonkoncentration koncentration

\section{forøget strain}

Fig. 3. Mechanostat-teorien: Figuren illustrever hvordan en lav koncentration af kønshormoner tenkes at oge set-point for knogledannelse $(B$ og $C)$. Dette resulterer $i$, at set-point forst nås $i$ tilfalde af et forgget strain fra mekanisk belastning $(C)$.

påvirkning, mens knoglenedbrydning vil være tilfældet, hvis strain vedvarende ligger under set-point. Imidlertid vil lave koncentrationer af kønshormoner øge set-point og medføre, at et større strain er nødvendigt for at lede til knogleopbygning (fig 3).

Anvendes denne teori på den kvindelige idrætstriade, kunne man tænke sig, at strain i fx redskabsgymnastik (forårsaget af muskelkraft og reaktionskraft fra underlaget) var stor nok til at overstige et forøget set-point (fig. 3, C), mens det ikke var tilfældet ved løb (fig 3, B). Mechanostatteorien kunne således bidrage til en forklaring på, hvorfor en lav knogletxthed associeret med hormonale forstyrrelser primært ses hos kvindelige idrætsudøvere med en relativ lav belastning af skelettet. Skulle denne hypotese vise sig at holde stik, kunne en logisk konsekvens i fremtiden blive at foreskrive muskelstyrketræning til løbere med symptomer på den kvindelige idrætstriade for at $ø g e$ BMD gennem en forøgelse af strain. En sådan strategi ville dog på ingen måde kunne stå alene, da den udelukkende ville være rettet mod symptomet og ikke selve årsagen, spiseforstyrrelsen og den lave energi-tilgxngelighed.

FOREBYGGELSE AF SPISEFORSTYRRELSER I IDRÆTTEN

De udløsende faktorer for udvikling af spiseforstyrret adfærd og kliniske spiseforstyrrelser kan selvsagt være mange, men generelt bunder det $\mathrm{i}$ en utilfredshed med 
aspekter af livet - det være sig i skolen, i idrætten, blandt kammeraterne eller i familien, og adfærden bliver et redskab til at fă kontrol over sig selv (præstation og/eller udseende) og sit liv. For at modvirke denne situation synes det af stor betydning, at idrætsudøverne oplever at have kontrol over deres egen træningssituation, fx gennem indflydelse på egen træningsproces og ansvar for sig selv og egen sundhed.

Som træner for eliteidrætsudøvere har man pligt til at holde sig orienteret om den kvindelige idrætstriade for at kunne informere og rådgive sine udøvere inden for dette felt og tage kontakt til eksperter på området, hvis man finder det nødvendigt. Det er vigtigt at precisere overfor idrætsudøverne, at lav kropsvægt kun er én blandt mange faktorer som har indflydelse på præstationevnen, som fx træningens indhold og tilrettelæggelse, kostens sammensætning og mentale, sociale og psykiske aspekter, samt at et utilstrakkeligt energiindtag i længden har en negativ konsekvens på både helbred og præstationsevne. Samtidig bør det anerkendes, at vedvarende menstruationsforstyrrelser skal tages alvorligt, da det er et tydeligt tegn på, at kroppen ikke fungerer normalt og kan være et symptom på den kvindelige idrætstriade.

Fra flere sider inden for både Danmarks
Idræts-Forbund og Team Danmark har der i de senere år været en øget fokus på spiseforstyrrelser og den kvindelige idrætstriade med mulighed for rådgivning og vejledning til både aktive og trænere/ledere på eliteplan. Samtidig vil det fremover være en forudsætning for tildeling af økonomisk støtte fra Team Danmark, at det enkelte specialforbund har formuleret og implementeret en klar ernæringspolitik. Man må håbe, at disse positive initiativer fra centralt hold hastigt vil brede sig ud og have en afsmittende effekt, også blandt subeliten og på klubniveau.

\section{LITTERATUR}

- American Psychiatric Association (1994): "Diagnostic and statistical manual of mental disorders (DSM-IV)". APA, Washington, DC.

. Cann, CE et al (1984): "Decreased spinal mineral content in amenorrheic women", in JAMA 1984/5.

- Drinkwater, BL et al (1984): "Bone mineral content of amenorrheic and eumenorrheic athletes", in N Engl J Med 1984/5.

. Frost, HM (1992): "The role of changes in mechanical usage set points in the pathogenesis of osteoporosis", in J Bone Miner Res 1992/7.

. Gibson, J (2000): “Osteoporosis", in Drinkwater BL (ed.). Women in Sport. Blackwell Science, Abingdon, Oxon.

- Der er en høj forekomst af spiseforstyrrelser i eliteidrætten.

- Især idrætsgrene med stor fokus på kropsvægt og udseende indebærer en risiko.

- Spiseforstyrrelser udgør sammen med amenorré og knogleskørhed den kvindelige idrætstriade.

- Jo længere varighed af menstruationsforstyrrelser, des større negativ påvirkning af knogletxtheden.

- Tidlig diagnosticering og behandling er afgørende for det videre forløb. 
. Harber, VJ, Petersen SR, Chilibeck PD (1998):

"Thyroid hormone concentrations and muscle metabolism in amenorrheic and eumenorrheic athletes", in Can J Appl Physiol 1998/23.

. Loucks, AB (2004): "Energy balance and body composition in sports and exercise", in J Sports Sci 2004/1.

. Marshall D, Johnell O, Wedel H (1996): "Metaanalysis of how well measures of bone mineral density predict occurence of osteoporotic fractures", in BMJ 1996/312.

. Petit, MA, Prior, JC (2000): "Exercise and the hypothalamus - ovulatory adaptations", in Warren, MP, Constantini, NW (eds.) Sports Endocrinology. Humana Press, Totowa, New Jersey.

- Smolak, L, Murnen, SK, Ruble, AE (2000): "Female athletes and eating problems: a meta-analysis", in Int J Eat Disord 2000/27.

- Sundgot-Borgen, J \& Torstveit, MK (2004): "Prevalence of eating disorders in elite athletes is higher than in the general population", in Clin J Sport Med 2004/1.

- Sundgot-Borgen, J (1994): "Risk and trigger factors for the development of eating disorders in female elite athletes", in Med Sci Sports Exerc 1994/4.

- Sundgot-Borgen, J (1999): "Eating disorders among male and female elite athletes", in $\mathrm{Br} J$ Sports Med 1999/33.

. Sundgot-Borgen, J (2000): "Eating Disorders", in Barbara Drinkwater (ed.) Women in Sport.

Blackwell Science, Abingdon, Oxon.

- Sundhedsstyrelsen (1997): Spiseforstyrrelser Hvor stort er problemet og hvordan kan man forebygge? Sundhedsstyrelsen, København.

- WHO (1992): The ICD-10 Classification of mental and behavioural disorders. Clinical descriptions and diagnostic guidelines. WHO, Geneva.

- Wulff Hansen, E (1988): Menstruation og idret en spørgeskemaundersøgelse blandt eliteidratskvinder $i$ Danmark. Danmarks Højskole for Legemsøvelser, København.
- Wulff Helge, E, Kanstrup, I-L (2002): ABMD in female elite gymnasts. Impact of muscle strength and sex hormone levels", in Med Sci Sports Exerc 2002/1.

- Yeager, K, Agostini, R, Nattiv, R, Drinkwater, BL (1993): "The female athlete triad: disordered eating, amenorrhea, osteoporosis", in Med Sci Sports Exerc 1993/25.

\section{SUMMARY}

In general, the lean healthy body is the ideal in society today, and especially in elite sports this is reinforced by a wish to achieve exceptional performance. For some athletes the striving towards a low body weight results in disordered eating or clinical eating disorders like Anorexia Nervosa and Bulimia Nervosa. This has a negative impact on most aspects of the athlete's life, but, first of all, it has serious negative health consequences.

Mostly, disordered eating/eating disorders are accompanied by a negative energy balance and this negative energy balance suppresses the hypothalamic-gonadal axis. The result is low concentrations of sex hormones and as a consequence menstrual disturbances - in women - and an increased risk of osteoporosis. The female athlete triad comprises firstly eating disorders; secondly menstrual disturbances and thirdly osteoporosis/low bone mineral density; however, a large mechanical impact from physical activity can decrease the risk of osteoporosis.

Eva Wulff Helge, cand.scient.

Institut for Idræt, Københavns Universitet 